\title{
DEVELOPMENT AND VALIDATION OF A GC-NPD/micro-ECD METHOD USING DUAL COLUMN FOR THE DETERMINATION OF BENZODIAZEPINE IN HUMAN WHOLE BLOOD AND PLASMA
}

\author{
FELIPE BRAVO ${ }^{1,2,3}$, CLAUDIO LOBOS ${ }^{2}$, KARINA VENEGAS ${ }^{2}$ and \\ JULIO BENITES $S^{1,3 *}$ \\ ${ }^{1}$ Departamento de Ciencias Quimicas y Farmacéuticas, Universidad Arturo Prat, Casilla 121, Iquique, Chile. \\ ${ }^{2}$ Laboratorio Referencial Norte. Servicio Médico Legal. Iquique, Chile. \\ ${ }^{3}$ Instituto de EtnoFarmacología (IDE), Universidad Arturo Prat. Iquique. Chile. Avenida Arturo Prat 2120. Casilla 121. Iquique. Chile. \\ (Received: May 17, 2010 - Accepted: November 3, 2010)
}

\begin{abstract}
Four benzodiazepines flunitrazepam, nitrazepam, clonazepam, and alprazolam, have been analyzed from biological matrices by dual column gas chromatography using a nitrogen-phosphorus detector (NPD) and a micro-electron capture detector (m-ECD). The recoveries of the four benzodiazepines spiked into human whole blood and plasma were 88.8 - 97.9 and $90.7-97.5 \%$, respectively. The regression equations for the four benzodiazepines showed excellent linearity. The detection limits (LODs) were $0.14-0.95 \mathrm{ng} / \mathrm{mL}$ for whole blood and $0.13-0.93 \mathrm{ng} / \mathrm{mL}$ for plasma. The method is simple and sensitive for the determination of benzodiazepines in human whole blood and plasma, and may be useful in forensic science practice.
\end{abstract}

Keywords: Benzodiazepines, gas chromatography, nitrogen-phosphorus detector, micro-electron capture detector.

\section{INTRODUCTION}

Clinical toxicological analysis is usually a single case analysis which must be available on a 24-hour basis. The method should be as rapid and precise as necessary for clinical diagnosis and therapy. Ideally, one single procedure should allow the detection of all relevant potential toxicants. Forensic toxicological analysis should also provide high reliability and accuracy in order to be defensible in court. The first step in toxicological analysis is the identification of the usually unknown drugs and poisons in body fluids. A Systematic Toxicological Analysis (STA) procedure is necessary that allows the simultaneous detection of as many toxicants as possible in biosamples. ${ }^{1}$ It is impressive how and how much STA, i.e., the screening for drugs and poisons, has advanced.

The diffusion of drug use, abuse, and misuse has brought about an increasing awareness that drugs are not only harmful to life, but may also affect different aspects of human behaviour (e.g., performance at work, in driving, in sports). ${ }^{2}$ As a consequence, new spectrofields of application of STA have come up (e.g., workplace drug testing, drugs and driving, antidoping control). ${ }^{3-5}$ The fact that therapeutic rather than toxic concentrations have to be searched for in such cases has put pressure on technological progress towards increasing the sensitivity of analytical techniques. ${ }^{2}$

Benzodiazepines are a large group of substances with a wide range of potency and physicochemical properties ${ }^{6}$ that are frequently prescribed for anxiety, sleep disorders, or convulsive attacks. Several analytical methods for the detection of multiple benzodiazepine drugs in human blood and urine samples have been reported using GC/MS, ${ }^{7-10} \mathrm{LC} / \mathrm{MS},{ }^{11,12}$ and LC/MS/ MS. ${ }^{13-18}$ Some of these drugs and their metabolites possess polar groups in their molecules that require derivatization prior to $\mathrm{GC} / \mathrm{MS}$ analysis. ${ }^{7-9} \mathrm{LC}$ MS(/MS) seems to be suitable for rapid simultaneous determination of these drugs compared to GC/MS, since the extracted sample can be applied without derivatization, and electrospray ionization (ESI) has the ability to ionize most basic drugs. ${ }^{11,13-18}$ However, long analytical time is often required in order to obtain sufficient chromatographic resolution of several tens of drugs using traditional LC/MS. ${ }^{19}$

We have developed a rapid and STA procedure in human whole blood and plasma for four low therapeutic dose benzodiazepines: flunitrazepam, nitrazepam, clonazepam, and alprazolam (Figure 1), by dual column gas chromatography using a nitrogen-phosphorus detector and a micro-electron capture detector. The combination of these two frequently used detectors within the same analytical instrument yields a new and powerful tool.<smiles>CN1c2ccc([N+](=O)[O-])cc2C(c2ccccc2F)NCC1O</smiles>

Flunitrazepam<smiles>O=[N+]([O-])C1CCC2NC(O)CNC(c3ccccc3Cl)C2C1</smiles>

Clonazepam<smiles>O=[N+]([O-])c1ccc2c(c1)C(c1ccccc1)NCC(O)N2</smiles>

Nitrazepam<smiles>Cc1nnc2n1Cc1ccc(Cl)cc1C(c1ccccc1)NC2</smiles>

Alprazolam

Figure 1. Structures of the four benzodiazepines studied: flunitrazepam, nitrazepam, clonazepam, and alprazolam.

\section{MATERIALS AND METHODS}

\section{Chemicals and reagents}

Flunitrazepam, nitrazepam, clonazepam, alprazolam, and prazepam were purchased from Cerilliant (TX, USA). Ethyl acetate (HPLC grade) was purchased from Fisher. Acetic acid, hydrochloric acid, methanol, and potassium dihydrogen phosphate (analytical reagent grade) were purchased from Merck. Ammonia and dichloromethane (GC grade) were purchased from Riedel-de Haën.

\section{Standard solutions}

Standard stock solutions of flunitrazepam, nitrazepam, clonazepam, alprazolam and prazepam (internal standard, I.S.) were prepared by dissolving each compound in methanol to get a concentration of $1 \mathrm{mg} / \mathrm{mL}$; the solutions were stored at $4{ }^{\circ} \mathrm{C}$ and remained stable for at least 24 months.

\section{Biological samples}

Samples of outdated whole blood and plasma were obtained from the blood bank of "Dr. Ernesto Torres Galdames" Hospital and stored at $-30{ }^{\circ} \mathrm{C}$ until analysis.

\section{Sample preparation}

Human whole blood or plasma were shaken for $1 \mathrm{~min}$ and then homogenized 
thoroughly. To the homogenate were added $25 \mathrm{~mL}$ of a $4 \mathrm{ng} / \mathrm{mL}$ solution of Prazepam (I.S.) and $2 \mathrm{~mL}$ of $100 \mathrm{mM}$ of $\mathrm{pH} 6.0$ phosphate buffer. The sample solutions were vortexed for $1 \mathrm{~min}$ and sonicated at room temperature for 30 min. After centrifugation at $4,000 \mathrm{rpm}$ for $15 \mathrm{~min}$, the samples were introduced in the extraction column.

\section{Solid-phase extraction (SPE)}

The solid-phase extraction was performed using a Bond Elut Certify column. The solid-phase extraction cartridges were preconditioned with $3 \mathrm{~mL}$ of methanol, $3 \mathrm{~mL}$ of water, and $100 \mathrm{mM} \mathrm{pH} 6.0$ phosphate buffer, all under vacuum (no more than $3 \mathrm{~mm} \mathrm{Hg}$ ). The prepared samples were then applied and allowed to pass through the column at a rate of 1 to $2 \mathrm{~mL} / \mathrm{min}$. The sorbent was washed with $3 \mathrm{~mL}$ of water, $1 \mathrm{~mL}$ of $100 \mathrm{mM} \mathrm{HCl}$ (or $1 \mathrm{~mL}$ of $1.0 \mathrm{M}$ acetic acid) and $3 \mathrm{~mL}$ of methanol. The vacuum was maintained at $15 \mathrm{~mm} \mathrm{Hg}$ for $10 \mathrm{~min}$ to dry the column completely. Finally, the benzodiazepines were eluted with $3 \mathrm{~mL}$ of dichloromethane-isopropanol-ammonia (78:20:2 v/v/v) into amber collection tubes. The eluate was evaporated under a gentle stream of nitrogen and the residue was redissolved in $100 \mathrm{~mL}$ of ethyl acetate.

\section{GC-NPD/micro-ECD}

Chromatographic analysis was carried out on an Agilent Series $6890 \mathrm{~N}$ system (Agilent, USA) equipped with an Automatic Sampler 7683 series linked with injector programmed temperature volatilization (PTV) and two DB-5MS capillary columns $(50 \mathrm{~m} \times 0.2 \mathrm{~mm}, 0.33 \mu \mathrm{m}$ film thickness $)$. The injection volume was $5 \mathrm{~mL}$ in solvent vent mode. A nitrogen-phosphorus detector and a micro-electron capture detector, together with a Chemstation software suite (Agilent, USA) version A.09 were used for data processing and instrument control. The temperature of the PTV injector in solvent vent mode was set at $100{ }^{\circ} \mathrm{C}$ and the flow rate was kept at $2 \mathrm{~mL} / \mathrm{min}$ using helium as the carrier gas. The oven temperature was programmed as follows: the initial temperature was set at $50{ }^{\circ} \mathrm{C}$, held for $4 \mathrm{~min}$, and ramped at $7{ }^{\circ} \mathrm{C} / \mathrm{min}$ to $200^{\circ} \mathrm{C}$, where it was held for $4 \mathrm{~min}$ and again ramped at $7{ }^{\circ} \mathrm{C} / \mathrm{min}$ to $300^{\circ} \mathrm{C}$ and held for $5 \mathrm{~min}$. The transfer line temperature was set at $300^{\circ} \mathrm{C}$.

The inlet and GC-NPD and GC-m-ECD interface temperatures were kept at $335^{\circ} \mathrm{C}$ and $345^{\circ} \mathrm{C}$, respectively.

\section{RESULTS AND DISCUSSION}

Solid phase extraction has some merits for sample preparation compared with liquid-liquid extraction: (1) very simple extraction procedure; (2) small solvent volume; (3) high throughput performance and feasibility of treating of many samples at one time; (4) minimization of differences among individuals. We have confirmed the usefulness of the Bond Elut Certify column for extraction of abused drugs from biological fluids. ${ }^{20}$

The presented system with double column and dual detector makes use of the advantages of micro-electron capture and selective nitrogen-phosphorus detection, while the importance of several disadvantages and problems of single detector systems is reduced. ${ }^{5}$ The cost of upgrading an m-ECD and NPD is low compared to the initial cost of purchasing the MS. ${ }^{5}$ The use of two equal columns and two specific detectors has led to greater selectivity because it uses two different physicochemical foundations that provide a similar retention time for the same drug. ${ }^{21}$ Another advantage is that one gets higher sensitivity (LOD) than other published studies using specific and sensitive detectors such as mass spectrometry. ${ }^{25,27-30,32}$ The combination of gas chromatography detectors presented here offers several possibilities for the routine analysis of benzodiazepines because they are compounds containing nitrogen atoms that can be located with the NPD and m-ECD for the presence the electronegative groups.

Tables 1 and 2 show linearity, signal to noise ratio $(\mathrm{S} / \mathrm{N})$, relative standard deviation (RSD), limit of detection (LOD), limit of quantitation (LOQ), and solid-phase extraction efficiency in whole blood and human plasma with dual detection, $\mathrm{m}-\mathrm{ECD}$, and NPD of each drug. The tested range of four low therapeutic dose benzodiazepines, flunitrazepam, nitrazepam, clonazepam, and alprazolam, in human whole blood and plasma was $0.5-100 \mathrm{ng} \mathrm{mL}^{-1}$, which sufficiently covers therapeutic concentrations (Tables 1 and 2).

The calibration curve was linear in the concentration range shown in Tables 1 and 2 for each drug, with correlation coefficients better than 0.99 . The ranges of linearity of the benzodiazepines studied were satisfactory with respect to the therapeutic range for forensic and clinical purposes.

Table 1. Linearity, signal to noise ratio (S/N), relative standard deviation (RSD), limit of detection (LOD), limit of quantitation (LOQ), and solid-phase extraction efficiency in human whole blood. (m-ECD and NPD detectors).

\begin{tabular}{|c|c|c|c|c|c|c|c|c|c|c|c|}
\hline \multirow{2}{*}{$\begin{array}{c}\text { Compound } \\
\text { Flunitrazepam }\end{array}$} & \multirow{2}{*}{$\begin{array}{c}\begin{array}{c}\text { Tested } \\
\text { range } \\
\left(\mathrm{ng} \mathrm{mL}^{-1}\right)\end{array} \\
0.5-12.5\end{array}$} & \multirow{2}{*}{$\begin{array}{c}\left(\mathrm{r}^{2}\right)^{\mathrm{a}} \\
\mathrm{m}-\mathrm{ECD} \\
0.995 \quad 0.999 \\
\end{array}$} & \multicolumn{2}{|c|}{$\begin{array}{c}\mathrm{S} / \mathrm{N} \\
\mathrm{m}-\mathrm{ECD} \mathrm{NPD}\end{array}$} & \multicolumn{2}{|c|}{$\begin{array}{c}\text { RSD } \\
\text { m-ECD NPD }\end{array}$} & \multicolumn{2}{|c|}{$\begin{array}{c}\text { LOD } \\
\left(\text { ng mL }^{-1}\right) \\
\text { m-ECD NPD }\end{array}$} & \multicolumn{2}{|c|}{$\begin{array}{c}\text { LOQ } \\
\left(\mathrm{ng} \mathrm{mL}^{-1}\right) \\
\text { m-ECD NPD }\end{array}$} & \multirow{2}{*}{$\begin{array}{l}\text { Whole Blood } \\
\text { SPE } \\
\text { efficiency }(\%) \\
93.7\end{array}$} \\
\hline & & & 0.030 & 0,005 & 1.79 & 2.65 & 0.04 & 0.08 & 0.14 & 0.25 & \\
\hline Nitrazepam, & $5-100$ & $0.999 \quad 0.998$ & 0.332 & 0,165 & 1.87 & 3.96 & 0.51 & 0.95 & 1.54 & 2.88 & 88.8 \\
\hline Clonazepam & $2.5-75$ & $0.999 \quad 0.997$ & 0.468 & 0,098 & 1.05 & 2.38 & 0.13 & 0.19 & 0.41 & 0.58 & 96.1 \\
\hline Alprazolam. & $2.5-100$ & $0.998 \quad 0.998$ & 0.031 & 0,054 & 2.08 & 4.68 & 0.29 & 0.41 & 0.88 & 1.23 & 97.9 \\
\hline
\end{tabular}

${ }^{a} \mathrm{r}^{2}=$ Square of correlation coefficient with a weighting factor of $1 /$ concentration.

Table 2. Linearity, signal to noise ratio (S/N), relative standard desviation (RSD), limit of detection (LOD), limit of quantitation (LOQ), and solid-phase extraction efficiency in human plasma. (m-ECD and NPD detector).

\begin{tabular}{|c|c|c|c|c|c|c|c|c|c|c|c|c|}
\hline \multirow{2}{*}{$\begin{array}{c}\text { Compound } \\
\text { Flunitrazepam }\end{array}$} & \multirow{2}{*}{$\begin{array}{c}\begin{array}{c}\text { Tested } \\
\text { range } \\
\left(\mathrm{ng} \mathrm{mL}^{-1}\right)\end{array} \\
0.5-12.5\end{array}$} & \multicolumn{2}{|c|}{$\begin{array}{c}\left(\mathrm{r}^{2}\right)^{\mathrm{a}} \\
\mathrm{m}-\mathrm{ECD} \mathrm{NPD}\end{array}$} & \multicolumn{2}{|c|}{$\begin{array}{c}\mathrm{S} / \mathrm{N} \\
\mathrm{m}-\mathrm{ECD} \mathrm{NPD}\end{array}$} & \multicolumn{2}{|c|}{$\begin{array}{c}\text { RSD } \\
\text { m-ECD NPD }\end{array}$} & \multicolumn{2}{|c|}{$\begin{array}{c}\text { LOD } \\
\left(\text { ng mL }^{-1}\right) \\
\text { m-ECD NPD }\end{array}$} & \multicolumn{2}{|c|}{$\begin{array}{c}\text { LOQ } \\
\left(\mathrm{ng} \mathrm{mL}^{-1}\right) \\
\mathrm{m}-\mathrm{ECD} \text { NPD }\end{array}$} & \multirow{2}{*}{$\begin{array}{c}\text { Human plasma } \\
\text { SPE } \\
\text { efficiency }(\%)\end{array}$} \\
\hline & & 0.999 & 0.999 & 0.034 & 0,001 & 2.21 & 2.34 & 0.05 & 0.08 & 0.14 & 0.23 & \\
\hline Nitrazepam, & $5-100$ & 0.999 & 0.998 & 0.303 & 0,161 & 2.64 & 5.04 & 0.52 & 0.93 & 1.58 & 2.80 & 90.7 \\
\hline Clonazepam & $2.5-75$ & 0.999 & 0.997 & 0.462 & 0,098 & 3.07 & 3.83 & 0.21 & 0.26 & 0.63 & 0.78 & 96.7 \\
\hline Alprazolam. & $2.5-100$ & 0.998 & 0.998 & 0.007 & 0,046 & 1.87 & 3.87 & 0.28 & 0.42 & 0.84 & 1.26 & 97.5 \\
\hline
\end{tabular}

${ }^{a} \mathrm{r}^{2}=$ Square of correlation coefficient with a weighting factor of $1 /$ concentration.

The signal to noise ratios of $\mathrm{m}-\mathrm{ECD}$ and NPD detectors are in the ranges of $0.030-0.468$ and $0.05-0.165$, respectively, in human whole blood, and of 0.07 -0.462 and $0.001-0.161$, respectively, in plasma. The limit of detection, defined as the lowest concentration of the analyte that can be clearly detected above the baseline signal, is estimated as three-times the signal-to-noise ratio. The LOD was determined $(n=6)$ by injection of human whole blood and plasma spiked with benzodiazepines in decreasing concentrations. The LOD was calculated based on the SD of the response and the slope (S) of the calibration curve(s) at levels approximating the $\mathrm{LOD}$ according to the formula: $\mathrm{LOD}=3.3(\mathrm{SD} / \mathrm{S})$. The $\mathrm{SD}$ of the response can be determined based on the $\mathrm{SD}$ of the blank, on the residual $\mathrm{SD}$ of the regression line, or the SD of the $y$-intercepts of the regression lines. ${ }^{22}$ The values obtained are listed in Tables 1 and 2. 
The limit of quantitation is the lowest concentration that can be measured on the standard curves with acceptable reproducibility. The LOQs determined for the four benzodiazepines tested allowed the measurement of subtherapeutic concentrations of these compounds. The calculation method is again based on the SD of the response and the slope of the calibration curve(s) according to the formula: $\mathrm{LOQ}=10(\mathrm{SD} / \mathrm{S})$. Again, the $\mathrm{SD}$ of the response can be determined based on the SD of the blank, on the residual SD of the regression line, or the SD of the $y$-intercepts of the regression lines. ${ }^{22}$ This experiment showed that the LOQs achieved with m-ECD detection are lower than those previously obtained with NPD detection in human whole blood and plasma.

The solid-phase extraction efficiency of the benzodiazepines in the $0.5-$ $100 \mathrm{ng} / \mathrm{mL}$ range was more than $88 \%$ in human whole blood and plasma as shown in Tables 1 and 2. The average recoveries were $94.1 \%$ for whole blood and $95 \%$ for plasma.

The usefulness of this method is shown comparing the literature levels with the LOD obtained in this study. The reproducibilities of m-ECD and NPD detectors are in the ranges of $1.05-2.08$ and $2.38-4.68$, respectively, in human whole blood, and of $1.87-3.07$ and $2.34-5.04$, respectively, in plasma. These values are below international requirements. ${ }^{22}$

This work showed the high sensitivity of our method GC-NPD/m-ECD using dual columns with various chromatographic methods published in the literature, such as HPLC/DAD ${ }^{23} \mathrm{HPLC} / \mathrm{MS} / \mathrm{MS},{ }^{24} \mathrm{GC} / \mathrm{MS},{ }^{25,28,32} \mathrm{GC} / \mathrm{MS} / \mathrm{MS},{ }^{8}$ HPLC/UV 26,31 and HPLC/MS, ${ }^{27,29,30}$ which are used for the determination of low therapeutic doses of benzodiazepines in human whole blood and plasma. According to the LODs from the literature shown in Table 3, our assay using the described Bond Elut Certify method of choice allows the detection and quantitation of flunitrazepam, nitrazepam, clonazepam, and alprazolam at subtherapeutic and toxic levels. This method is simple, sensitive and may be useful in forensic science practice in cases of drug facilitated crimes, acute poisoning, and traffic accidents.

Table 3. Limit of detection (LOD) of benzodiazepines studied by various chromatographic methods published in the literature.

\begin{tabular}{|c|c|c|c|c|}
\hline BZD & Matrix & Detection & LOD (ng/mL) & Reference \\
\hline $\begin{array}{c}\text { Clonazepam } \\
\text { Flunitrazepam }\end{array}$ & Blood & HPLC/DAD & 3.5 & 23 \\
\hline Flunitrazepam & Plasma & HPLC/MS/MS & 0.25 & 24 \\
\hline $\begin{array}{l}\text { Flunitrazepam } \\
\text { Nitrazepam } \\
\text { Clonazepam } \\
\text { Alprazolam }\end{array}$ & Blood & GC/MS & $\begin{array}{c}3.1 \\
56 \\
3 \\
9\end{array}$ & 25 \\
\hline $\begin{array}{l}\text { Flunitrazepam } \\
\text { Nitrazepam } \\
\text { Alprazolam }\end{array}$ & Blood & $\mathrm{GC} / \mathrm{MS} / \mathrm{MS}$ & $\begin{array}{c}100 \\
100 \\
1000\end{array}$ & 8 \\
\hline Clonazepam & Plasma & HPLC/UV & 2 & 26 \\
\hline $\begin{array}{c}\text { Alprazolam } \\
\text { Flunitrazepam }\end{array}$ & Plasma & HPLC/MS & $\begin{array}{l}0.5 \\
0.5\end{array}$ & 27 \\
\hline $\begin{array}{l}\text { Alprazolam } \\
\text { Nitrazepam }\end{array}$ & Blood & GC/MS & $\begin{array}{l}5 \\
5 \\
\end{array}$ & 28 \\
\hline Alprazolam & Plasma & HPLC/MS & 1 & 29 \\
\hline $\begin{array}{l}\text { Clonazepam } \\
\text { Alprazolam } \\
\text { Flunitrazepam }\end{array}$ & Plasma & HPLC/MS & $\begin{array}{c}0.2 \\
0.2 \\
2\end{array}$ & 30 \\
\hline $\begin{array}{c}\text { Flunitrazepam } \\
\text { Clonazepam }\end{array}$ & Plasma & HPLC/UV & $\begin{array}{l}20 \\
20\end{array}$ & 31 \\
\hline $\begin{array}{c}\text { Alprazolam } \\
\text { Clonazepam } \\
\text { Flunitrazepam }\end{array}$ & Blood & GC/MS & $\begin{array}{l}1.36 \\
3.09 \\
0.52\end{array}$ & 32 \\
\hline
\end{tabular}

Table 4 shows retention time and the method's precision determined by measuring repeatability (intra-day precision) and reproducibility (inter-day precision) of peak areas for clonazepam and alprazolam, because both drugs are used in high percentages in outpatient treatment in Chile. The intra-day precision of the clonazepam and alprazolam concentrations examined was $1.2 \%$ and $1.7 \%$ with the m-ECD detector and $2.5 \%$ and $4.3 \%$ with the NPD detector, respectively. The inter-day precision of the clonazepam and alprazolam concentrations examined was $0.57 \%$ and $0.33 \%$ with the $\mathrm{m}$-ECD detector and $1.36 \%$ and $1.65 \%$ with the NPD detector, respectively.

Table 4. Retention time and intra- and inter-day precision for clonazepam and alprazolam (m-ECD and NPD detector).

\begin{tabular}{|c|c|c|c|c|c|c|}
\hline Compound & $\begin{array}{c}\text { m-ECD } \\
\text { detector } \\
\text { Retention } \\
\text { time (min) }\end{array}$ & $\begin{array}{c}\text { NPD detector } \\
\text { Retention } \\
\text { time (min) }\end{array}$ & $\begin{array}{c}\text { m-ECD detector } \\
\text { Inter-day precision } \\
\text { RSD (\%) }\end{array}$ & $\begin{array}{c}\text { m-ECD detector } \\
\text { Intra-day precision } \\
\text { RSD (\%) }\end{array}$ & $\begin{array}{c}\text { NPD detector } \\
\text { Inter-day precision } \\
\text { RSD (\%) }\end{array}$ & $\begin{array}{c}\text { NPD detector } \\
\text { Intra-day } \\
\text { precision } \\
\text { RSD (\%) }\end{array}$ \\
\hline Clonazepam & 30.46 & 30.38 & 0.57 & 1.2 & 1.36 & 2.53 \\
Alprazolam & 31.75 & 31.68 & 0.33 & 1.7 & 1.65 & 4.30 \\
\hline
\end{tabular}

RSD: relative standard deviation 
Figs. 2 and 3 show the mass chromatograms obtained by dual column gas chromatography using a micro electron capture detector and a nitrogenphosphorus detector, respectively, which had been spiked with human whole blood and plasma samples obtained from the blood bank of the 'Dr. Ernesto Torres Galdames"' Hospital in Iquique, Chile.

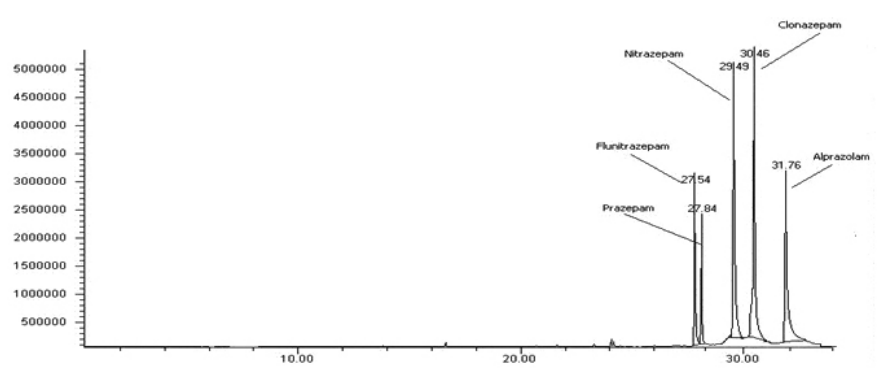

Figure 2. Mass chromatograms of the benzodiazepines analyzed from biological matrices by dual column gas chromatography using a micro-electron capture detector (m-ECD).

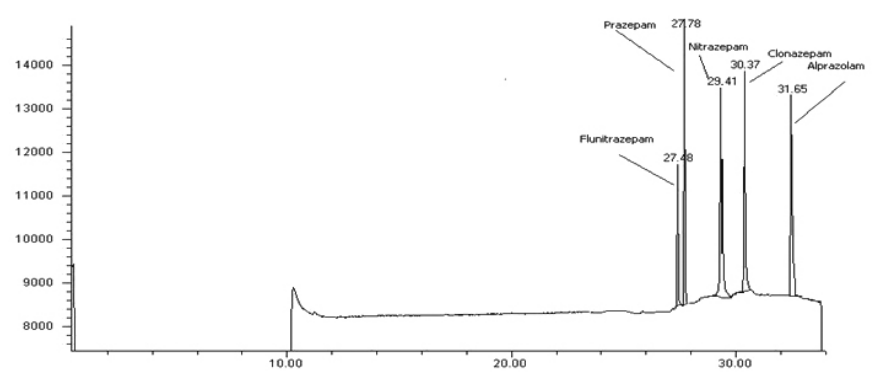

Figure 3. Mass chromatograms of the benzodiazepines analyzed from biological matrices by dual column gas chromatography using a nitrogenphosphorus detector (NPD)

\section{CONCLUSION}

We developed a rapid, highly sensitive, selectively and reproducibility method for four low therapeutic dose benzodiazepines, flunitrazepam, nitrazepam, clonazepam and alprazolam, in human whole blood and plasma using dual column gas chromatography with a nitrogen-phosphorus detector and a micro-electron capture detector. This combination of gas chromatography detectors offers several possibilities for routine analyses: for general unknown analyses, suspected pharmacologically active compounds containing nitrogen or phosphorous atoms can be detected with the NPD/mECD and identified by MS. This method will be useful in the analysis of forensic and clinical toxicological cases.

\section{ACKNOWLEDGEMENTS}

The financial support of Universidad Arturo Prat and Servicio Medico Legal, Iquique, is gratefully acknowleged.

\section{REFERENCES}

1. H. H. Maurer, T. Kraemer, O. Ledvinka, Ch. J. Schmitt, A. A. Weber, $J$. Chromatogr. B, 689, 81, (1997).

2. A. Polettini, J. Chromatogr. B, $\mathbf{7 3 3}$ 47, (1999).

3. R.A. de Zeeuw, Toxicol. Lett. 102-103, 103, (1998).

4. D.R. Mottram, Sports Med. 27, 1, (1999).

5. A. Beat, B. Werner, Forensic Sci. Int. 102, 91, (1999)

6. O.H. Drummer, Forensic Sci. Int. 142, 101, (2004)

7. T. Gunnar, K. Ariniemi, P. Lillsunde, J. Chromatogr. B, 818, 175, (2005).

8. S. Pirnay, I. Ricordel, D. Libong, S. Bouchonnet, J. Chromatogr. A, 954, 235, (2002).

9. D. Borrey, E. Meyer, W. Lambert, S. Van Calenbergh, C. Van Peteghem, A.P. De Leenheer, J. Chromatogr. A, 910, 105, (2001).

10. H. Inoue, Y. Maeno, M. Iwasa, R. Matoba, M. Nagano, Forensic Sci. Int. 113, 367, (2000).

11. H. Miyaguchi, K. Kuwayama, K. Tsujikawa, T. Kanamori, Y.T. Iwata, H. Inoue, T. Kishi, Forensic Sci. Int. 157, 57, (2006).

12. C. Kratzsch, O. Tenberken, F.T. Peters, A.A. Weber, T. Kraemer, H.H. Maurer, J. Mass Spectrom. 39, 856, (2004).

13. B.E. Smink, M.P.M. Mathijssen, K.J. Lusthof, J.J. de Gier, A.C.G Egberts, D.R.A. Uges, J. Anal. Toxicol. 30, 478, (2006).

14. B.E. Smink, J.E. Brandsma, A. Dijkhuizen, K.J. Lusthof, J.J. Gier, A.C.G. Egberts, D.R.A. Uges, J. Chromatogr. B, 811, 13, (2004).

15. M. Laloup, M.R. Fernandez, G. Boeck, M. Wood, V. Maes, N. Samyn, $J$. Anal. Toxicol. 29, 616, (2005).

16. O. Quintela, F.-L. Sauvage, F. Charvier, J.-M. Gaulier, G. Lachâtre, P. Marquet, Clin. Chem. 52, 1346, (2006).

17. M. Nakamura, T. Ohmori, Y. Itoh, M. Terashita, K. Hirano, Biomed. Chromatogr. 23, 357, (2009).

18. S.J. Marin, R. Coles, M. Merrell, G.A. McMillin, J. Anal. Toxicol. 32, 491, (2008).

19. T. Ishida, K. Kudo, M. Hayashida, N. Ikeda, J. Chromatogr. B, 877, 2652, (2009).

20. J. P.Franke, R. A. de Zeeuw, J. Chromatogr. B, 713, 51, (1998).

21. M. Repetto, G. Repetto, Toxicología Fundamental, Ed. Díaz de Santos, España, $4^{\text {ta }}$ Edition, 2009, 536-537.

22. Sh. A. Ghulam, J. Chromatogr. A, 987, 1-2, 57, (2003).

23. A. El Mahjoub, C. Staub, J. Pharm. Biomed. Anal. 23, 447, (2000).

24. M. Kollroser, C. Schober J. Pharm. Biomed. Anal. 28, 1173, (2002).

25. S. Skurtveit, B. Abotnes, C. Asbjørg, Forensic Sci. Int. 125, 75, (2002).

26. B. Forfar, P. Fabienne, J. Christian, J. Pharm. Biomed Anal. 36, 865, (2004).

27. O. Quintela, A. Cruz, A. de Castro, M. Concheiro, M. Lopez-Rivadulla, $J$. Chromatogr. B, 825, 63, (2005).

28. G. Teemu, A. Kari, L Pirjo, J. Chromatogr. B, 818, 175, (2005).

29. O. Quintela, P. López, A.M. Bermejo and M. López-Rivadulla, J. of Chromatogr. B, 834, 188, (2006).

30. I. Tomomi, K. Keiko, H. Makiko, I. Noriaki, J. of Chromatogr. B, 877, 2652, (2009).

31. K. B. Borges, E. Figueiredo, I. Martins, M. Pereira Bastos de Siqueira, Talanta 78, 233, (2009)

32. I. I. Papoutsis, S. A. Athanaselis, P. D. Nikolaou, C. M. Pistos, Ch. A. Spiliopoulou, C. P. Maravelias, J. Pharm. Biomed. Anal. 52, 609, (2010). 